\title{
FUTURE DIRECTIONS IN LAW AND POPULAR CULTURE: a British perspective
}

\section{Law and Popular Culture and its spread}

Law and popular culture has truly come of age. The books, collections of essays and individual essays which have been published over the past 20 years constitute a clear and growing area of academic endeavour on film (see Bibliography ) and to a lesser extent television (ibid). Most recently scholars have reached out to emphasise the links with other related fields (see Wagner and Sherwin (2014); Ogletree and Sarat (2015); Sharp and Leiboff (2016); Picart, Jacobsen and Greek (2016)). There have been, however, limited links with the related field of law and literature and few individual scholars work in both areas. There is a wealth of both material as well as a range of different approaches. Some of these show the way in which the use of popular culture can supplement legal study and involve truly imaginative approaches to areas of scholarship (Robson (2005)). As with much intellectual endeavour there is scholarship which uses specialist language which demands a high degree of sophistication from the audience. There is also always the issue of methodology. In essence, why readers should find writers' comments and analysis convincing is not always made entirely clear.

Studies in the field of law and popular culture are paradoxical. They are, on the one hand, highly international. We watch, it seems, the same films and see the same television series whether we are in North America, Europe or Australia. Developments, however, are significantly local affairs. Our legal systems are markedly different, whether it be approaches - common law to Codes - or personnel - elected judges to professional civil servants. Our educational practices are quite distinctive. The role of the media in the shaping of perceptions of law and justice are determined by very different histories (Asimow M; Greenfield, S; Guillermo J; Machura S; Osborn G; Robson P; Sharp C and Sockloskie R (2005)). 
The impact and resonance, then, of much of what we are looking at and discussing, is different. This may well explain the rather different directions in which work is developing.

This comment on the future of law and popular culture suggests reasons as to why some of these developments have taken place. The perspective recognises the particularity of different cultural backgrounds. The account from Australian scholars of the emergence of cultural legal studies is specific to the Antipodes (Sharp and Leiboff (2016)). The German perspective on law and film, too, demonstrates quite specific elements, (Machura (2016))

as do those accounts from American scholars (Sarat (2009). Whilst recognising these differences, there are, however, many areas of congruence which this essay seeks to address. It also indicates some of the problems that the developments are likely to produce. The common problems resolve themselves into related matters of methodology, the use of language and issues of focus. A possible way forward with an unambiguous focus, clear methodology and simple language is provided to counter the notion that the critical elements in this essay amount to no more than negative carping with no alternative programme suggested. It examines areas of justice on television which are both specific to Britain but which, it is suggested, illustrate much broader themes of relevance outwith this jurisdiction and which are based on a close reading of material in its historical and material context.

\section{Legal Scholarship in Context}

In order to appreciate how cultural legal studies might develop it is worth going back to the problematic nature of legal studies themselves. Most disciplines have debates about methodology. Legal education has an even more fundamental underlying conflict since it is involved in training for the legal profession and legal practice as opposed to a discrete intellectual inquiry. There has always been a split on what one is aiming to achieve with the process. This is, admittedly, less of an issue for 
those from cognate disciplines. The majority of the scholarship, however, which we are involved in here comes from within the world of law and legal studies.

The approach one takes to uncovering the nature of law and how it operates depends crucially on the questions one wants answered. These in turn depend on who is making the inquiries and in what circumstances. The questions which a bright young student of law is likely to ask about the operation of justice are perhaps likely to be centred more on how justice is achieved than the immediate concerns of a lawyer representing poor or disadvantaged clients. These are more likely to be more concerned with rather more mundane matters such as "will my client be able to stay in their current accommodation". He or she will be aware that the big questions of the fairness of the system may have to wait for another day, irrespective of how important they may actually be in determining, for instance, that minority ethnic applicants never achieve success before particular judges. The broader social context, too, is highly important. The significance of what the common law or statutory position of anyone seeking legal assistance is hugely affected by whether or not the justice system is perceived to be fair and open to all. It may be, however, that not having money denies people access to proper advice and representation. It may also be that being a certain sex, ethnicity or sexuality is known or thought to affect one chances before the law, either in terms of the way the rules are applied or enforced. So, taking this into account, it should be clear that which particular approach is adopted, does not take place in some kind of vacuum in which people opt to become "doctrinal" lawyers or "socio-legal" lawyers. It is more a question of teasing out what approach best serves one's immediate purpose. The overarching concern of many has been to uncover how it is that the legal system which promises so much in terms of the equal treatment of the laws, so consistently operates in the interests of the few against the interests of the many and why this is either not known about or allowed to happen without greater social conflict. It is to answer questions like this that scholars have asked not just questions about the impact of particular sets of rules but more importantly what contribution is made to this situation by the way law is represented in books, films 
and on television. This is the most recent kind of approach found in Law Schools. It links, however, with issues which have fascinated scholars since the dawn of modern legal education and beyond.

\section{Modern Legal Scholarship}

It is a paradox that the apparently newest approach to examining and understanding law has, in fact been with us since the emergence of formal legal education. In Britain this did not emerge until the $19^{\text {th }}$ century. Law Faculties have been in existence for many centuries before this but with a limited role in the preparation of legal profession. This was done by the professions themselves (Abel Smith and Stevens (1965).

Legal education as distinct from in-house professional training for lawyers by the profession has only been with us in the United Kingdom since the 1870s (Robson (1979) (Robson 2012)). Until the reform of legal education the then limited number of Universities had Faculties of Law and Professors who wrote on a range of practical and philosophical issues. What they did not have, however, was students. They did not offer degrees. There were some desultory courses offered to trainee lawyers but the reports to the Committee of Legal Education in 1865 from the great institutions of learning in the middle of the $19^{\text {th }}$ century paint a sorry picture. When Universities started to take undergraduates and offer courses in law from the 1870 s there were two approaches. One was to offer a degree in the style we are familiar with today from the United States - the postgraduate first degree. This focused on the details of the operation of the legal system and was geared towards teaching professional practical subjects to those graduates who had commenced working in the legal profession. These young men - and they were, by order of the courts (Jex-Blake v Senatus of Edinburgh University 187311 M 784), all men - had received their education at University already with a degree, usually in some Arts subject so were in some sense "educated". The degree could focus on those areas of practice which were central to the working life of the lawyer. Teaching on these part-time degrees, for instance, was undertaken at the beginning of the day, at lunchtime and at teatime to enable these new graduates to combine their study with full- 
time work as trainee lawyers. The second approach which many lawyers opted for was the in-house training route. Here would-be lawyers completed a period of service in legal firms as articled clerks or apprentices while taking examinations set by the local legal professional societies. It was in this context of focused professional training that legal education as a distinct degree for school leavers commenced on a broad scale.

Debates about what should be in the legal syllabus, which were later encountered during the expansion of higher education in the 1960s, and the dominance of the full time degree addressed the crucial issue of balance (Robson 1979). On the one hand there was the focus on professional training and the day-to-day practical concerns of the profession to have useful well-trained staff joining them from University. On the other hand it was recognised that there was a need for wouldbe lawyers to reflect on the nature of law and its relationship with justice. This featured heavily in all the debates on the nature and function of the law degree. There was consensus that there was more to a University law degree than merely providing training for the profession. Education required more and this was recognised in the inclusion of compulsory subjects like Jurisprudence and somewhat bizarrely, Forensic Medicine. These would allow the formation of fully rounded lawyers for the future, capable of disputation and contemplation above the narrow details of the common law and emerging statutory codes and the dangerous view that the law is the law. The aim was to produce the kind of lawyer whom the distinguished lawyer and internationally recognised novelist, Sir Walter Scott talked of when he distinguished between the lawyer as "a mechanic, a mere working mason" and one with some knowledge of history or literature who might call himself "an architect" (Guy Mannering (1815) Ch 37).

The point about law and popular culture is that it takes us into a realm of enterprise which sociolegal scholars have, as yet, ventured only in a very limited way. It completes the circle of enquiry about how law and justice really operate. It looks not just at the actions and practices of the justice system, but at what factors help to drive the success or failure of laws and legal systems. By taking 
seriously the culture of law in the form in which the system is presented to the public it can help give a richer picture than previously available. It is not, however, ever likely to be the dominant approach to law but it provides rich possibilities to complement other scholars' work. The difference is not so much in the different methodologies adopted, however, but rather the kinds of questions which are posed. It has emerged in a variety of different forms.

\section{Law and literature}

One of the by-products of the $19^{\text {th }}$ century debates was the notion that popular culture could provide an insight into the legal process. As long ago as 1913 John Marshall Gest's The Lawyer in Literature was the first of a stream of writing about law which showed the link to literature. Building on Wigmore's 1908 list of legal novels, this early collection of the more literary thinking from within the legal community was very much in the spirit of establishing the lawyer as a fully rounded scholar and was followed by other such collections. We find this approach most recently in the 1998 selection The Literature of the Law with its selection of extracts from some of the more literary passages from judgments of common law judges on topics as diverse as law and the downtrodden, law in wartime, the law and justice and judicial infirmities(Harris (1998)).

As Michael Freeman points out, this link to literature was the recognition of something that has fascinated writers and scholars for hundreds of years (Freeman (2005) at 1). Freeman noted that law's engagement with popular culture goes back to the mists of time. Within the Old Testament there are jurisprudential issues aplenty and these expand greatly in Ancient Greece. The themes and issues which Freeman adverts to have, in fact, formed the very stuff of this first way of linking law and popular culture. With their roots in Gest's collection there has been scholarship on the interface between law and literature for the past century. In addition to essays appearing in mainstream legal journals, there has been the Journal of Law and Literature since 1969 - originally this appeared as the 
Cardozo Studies in Law and Literature and was published under that title until 1996 - and the Columbia Journal of Law and the Arts. Their pages catalogue a vast store of scholarship which examines the literature and law relationship in two principal ways. The less practiced approach is to study the literary forms which judges and lawyers employ in their work. Most people do not read traditional legal texts and the interest remains strictly within the legal community. There is, in addition, a focus on how law is represented within literature. What this involves is looking to what examining works of literature can bring to the understanding of law both within the legal community and outwith it. This is of particular importance in the process of legal education. The editors of one collection of essays on law and literature, for instance, suggested that drawing on the insights of literature allows key legal issues to be brought to life in ways which orthodox legal materials cannot rival (Morison and Bell (1996) at 1).

This is the principal focus of much of law and literature's scholarship. The 1999 volume of the prestigious Current Legal Issues series from the University of London was devoted to Law and Literature and spans over 750 pages. There are some 32 essays with coverage of playwrights such as Shakespeare and Ibsen and such novelists as Scott, Hardy, Edgar Allen Poe and Angela Carter. Not only are legal themes mined within literary sources but there is also some attention paid to the literary elements within traditional legal sources such as trials. The contents, however, indicate that the interests of many scholars are with quite specific areas such as the Guernsey Witchcraft Trials of 1617 and the captivity of native North American children. The later collection under the broader heading of Law and Popular Culture appeared in 2005 and continues this splatter gun approach. The vast storehouse of literature is raided by scholars to provide a launch pad for developing arguments on such issues as children's literature, Gothic novels, JG Ballard's work and jurisprudence. Within the specialist Journals, putting aside the permanent fascination with Shakespeare, there is no unifying theme or themes but only a restless search by scholars for new ways to illustrate their current pre- 
occupations whether it be Bertolt Brecht, Arthur Miller's The Crucible, Herman Melville's Bartleby, the Scrivener or Laurence Stern's Tristram Shandy.

It is evident, then, that the area flourishes today. In addition to the literature and journals noted, there are courses on law and literature available in many Law Schools and the programme of the Association for the Study of Law, Culture and Humanities provides a focus for those working in this area. The work of law and literature scholars sits alongside that of writers on the products of the $20^{\text {th }}$ century, the cinema and TV. It is, however, quite distinct. It maintains the approach which first animated people to link law and literature. It is worth doing because, like scholarship on Shakespeare, the Romantic Poets or French Realists, it can tell us something profound about human nature and human motivation. As Lincoln Faller put it

[I]iterary texts are...able to escape or smooth over strongly felt contradictions in belief and practice that other kinds of texts have difficulty dealing with. This can make them powerful instruments for 'solving' social and political problems...or alternatively escaping the insufficiency in the face of such problems of other, supposedly more reality-orientated forms of discourse (Faller (1993) xv [cited in Morison and Bell at 1]).

This, then is the promise and potential insight provided by law and literature. It allows us at its best to contemplate such "contemporary" issues as consent, power and rape by looking at the relationship between Alex and Tess in Tess of the D'Urbevilles afresh (Freeman and Lewis (1999) per Melanie Williams at 167) or the broader theme of violence against women (Graycar (1996). The work of Alice Walker in The Color Purple similarly provides an element of distance from people's own preconceptions and perspectives to allow debate to be framed in a way with which people are likely to be less threatened. By looking through the eyes of characters, the issues are no less real but less personalised. An overview of the scholarship shows two things. It demonstrates that there is a 
wealth of material and issues with which to engage. It also highlights two of the reasons why this is an area which has been seen as marginal. The texts are not always accessible. There is in some of most feted writing a curious style which mixes standard academic discussions of footnoted propositions with soaring high flown literary imaginings. Reading the works of such writers as Goodrich (Goodrich (1996)) and Aristodemou (Aristodemou (2000), for instance, is often akin to reading a novel. Some critics within academe find these works hugely inspiring and liberating. To others they are largely impenetrable. They are certainly a challenge to any student commencing their study of law. Lawyers have to get used to being perplexed but it does not aid an approach when insights are hard to glean because of the method of expression. It is a problem which cannot be shirked that literary criticism is an area where pellucid exposition is not always in the ascendant. The language is frequently at best murky. The writings examined by scholars tend not to engage with any contemporary writing. Thus we find Posner looking at Homer, Shakespeare, Dickens, Dostoevsky and Kafka. Greek myths feature heavily in the scholarship of law and literature and a strong intellectual pedigree is essential. Engagement with more recent work is rare (Meyer (2001); Robson (1996) and (2014). The expansion of the legal novels from the early 1990s with the work of Grisham, Turow, Bernhardt and a whole host of others has been largely ignored in favour of "classics".

So here we have a niche area with a recognised body of scholarship and adherents who still face the suspicion that what they are doing is merely a diversion or amusement for the high-minded. The problem for those seen as offering no more than playful comments on law in great literary works is to connect this enterprise to the rest of the syllabus of the average law student. As a "sideline" for academics it may be guaranteed to preserve, and perhaps enhance, status but is not a viable career path and threatens to be always on the margins. The potential to become more engaged with the issues of the day, however, is there. Discussions on the thin lines between anarchy, law and order and a police state can often be highlighted effectively through fictional characters and analysing their actions as well as themes like the impact of feminism $\left({ }^{1}\right.$ Freeman and Lewis (1999) per Maria Aristodemou at 191 and Michael Thomson at 219 ; Thornton (2002)). There is, though, no sign of any 
kind of work to link the interpretation of these books and plays with how the public perceive them and what impact they might make. This potential for engagement outwith the narrow group of fellow scholars into civil society is a major feature behind developments since 1996 in relation to the visual media. As we shall see, however, here the temptation of academics to engage in arcane debates remains. It is in this area that the more recent excursions into the visual media offer both parallels and, potentially, an alternative.

\section{Law and Film}

The emergence of an interest in law and film as a major focus in publishing terms has occurred in the twenty years since 1996 with some 18 books, 10 edited collections and 8 special Journal issues in the area (These appear in the attached Bibliography and in Robson and Silbey (2012) Introduction). It seems clear that this is an area with considerable potential. As indicated at the start of this essay, however, there are problems which need to be explored. The rise in film and law has a clear foundation stone. It is the assertion and perception that film influences how we see law and justice. This has been the fundamental notion that has inspired writers to explore a range of films. Looking at popular culture also stems from and complements concerns within traditional Sociology of Law and Socio-Legal studies with the social construction of law and its socio-political nature. What has emerged has been a raft of work with both practical and intellectual concerns.

The concern of the earlier scholarship was to draw attention to how law was mis-portrayed in film as well as to use the visual media simply to capture the attention and interest of law students. The use of film as an illustrative teaching/pedagogic tool continues to be a worthwhile focus for lecturers and students alike. Much scholarship has been on individual films (see for example Puaux (2002), Nieto and Fernandez (2004) and Strickland, Foster and Banks (2006)). It has been complemented by rather more ambitious attempts to use film's content to illustrate changes in the way social issues 
are treated and who wields power in society (Greenfield, Osborn and Robson (2001) and (2010)). Film portrayals and the issues covered and not covered have been used to chart the rise of women lawyers, for instance and the changes in the ways oppressed minorities have been treated. From I am the Law (1939) through Adam's Rib (1949) and Jagged Edge (1987) to Legally Blonde (2000) we can see the changes in the visibility and role of women in the law. The fate of ethnic minorities and the LGBT community under the law has received rather less coverage (Moran (2004)). Mainstream film material has, until recently (Brokeback Mountain (2005); I Love You Phillip Morris (2009); Behind the Candelabra (2013)), been rather scarcer. Again this material whether, utilised in individual doctrinal law classes, theory courses like Jurisprudence or Sociology of Law or in bespoke Law and Film courses meets the need for a modern version of the rounded lawyer. There are, however, two developments, which link law and popular culture with socio-legal studies and professional concerns and which seem likely to provide much of the reason to believe that this visual media focus of modern law and popular culture can break out of the ghetto of academic marginalisation which has bedevilled law and literature.

Firstly there is the application to legal practice of the techniques of storytelling and rhetorical persuasion which can be observed in cinema. In much of Western legal culture the adversarial nature of the legal process involves the techniques of persuasion as much as technical legal knowledge. The ways in which both juries and lawyers understand the process of legal decisionmaking suggests that legal material is increasingly presented in cinematic terms. It is not just that juries expect the cases to resemble what they have seen on screen. Lawyers and judges themselves derive their role models within practice from fictional presentations of law (Meyer (2001)). This interpenetration of reality and popular culture means that the scope of law and popular culture has moved beyond testing the fictional against the "real". The "real" is constructed by lawyers who tactically mould their arguments to fit into their audience's popular cultural expectations (Sherwin 
(2000)). This is done both in technological terms and in narrative terms. Juries are assisted by a range of audio-visual aids. In complex trials the issues are presented in the narrative forms with which the jury is familiar, that of the fictional film or TV trial. This development has important implications for the next generation of lawyers as well as for those with an interest from a theoretical angle on the representation of the law and its actors within popular culture and is important for the Law School of the 21st century.

The second link which has made limited headway but which promises for the future is the attempt to link the ruminations of scholars on the likely impact of the media on people's behaviour with concrete empirical evidence. Rather than simply assume that the media have an impact on behaviour and that is why governments have always tried to censor what the people can see, there are now studies which seek to illustrate exactly how this occurs. This was done in 1973 by Vincenzo Tomeo in II Giudice Sullo Schermo but no English translation has yet been published although I have this in hand. Jessica Silbey has pointed out that there has been a split of emphasis between "law" and "film" somewhat akin to the "law in literature/law as literature" split noted above. This "law-infilm" part looks at how debates within law are conducted within film. How does law order our world in film? Within this broad field of "Law-in-film", Silbey has noted that this scholarship looks at how film shapes our expectations of law and justice in the world at large. Her suggestion "film, no less than law, (my emphasis) changes our perceptions of reality" is one thing which is the bedrock of interest in law and popular culture (Silbey (2007) at 567). Other writers, from Macaulay (Macaulay (1987) ) to Sherwin (Sherwin (2000) to Denvir (Denvir, John (2004)) have made similar suggestions. It has been driven by the exposure of people in the $20^{\text {th }}$ century to film and then television. Steven Stark estimated that by the time a child in America in the 1980s had reached secondary school age they had been exposed to some 10,000 hours of television on crime and that this shaped their 
outlook on law and order issues (Stark, Steven (1987)). Assessing it, however, he suggested was a far from easy task.

The position remains remarkably similar over 30 years later (Robson and Schulz (2016) passim). In the $21^{\text {st }}$ century there have been a number of attempts to address it. For example, one team of international scholars conducted a study across six disparate jurisdictions on the ways in which law students derive their notions about justice and its relation to law. This revealed that the media including films and TV, did indeed play a major role in the formation of ideas about justice and the legal system (Asimow M; Greenfield, S; Guillermo J; Machura S; Osborn G; Robson P; Sharp C and Sockloskie R (2005)). By contrast, Kimberlainne Podlas (Podlas (2009) and (2012)) as well as Salzmann and Dunwoody have examined the impact of television and found its impact to be rather less than had been assumed (Salzmann and Dunwoody (2005)). Further attempts to assess the impact of the media on audiences have been chronicled by Machura, (Machura (2011) ) as well as later related work by Machura, Love and Dwight (Machura, Love and Dwight (2014). Although these are all limited studies they do indicate the beginnings of a potentially valuable link between law and popular culture and with socio-legal approaches to legal phenomena.

The rather less well-trodden path of some scholars in the field is to suggest that " ffilm-as-law" is a study of filmic practices that are as pervasive and effective as legal ones in the ways in which they influence and inspire social order' (Silbey (2007) at $557 \mathrm{fn} 29$ ). This film studies focus has been noted and there have been various attempts made to utilise the insights from this other discipline. Dominated though as the field is by those with a legal rather than film studies background, this has not proved a fertile area. It does, however threaten to shift the area into a kind of self-indulgent emphasis with the nuances of film theory at the expense of engaging those coming from a legal angle. James Elkins has explained that it is precisely because there is an emphasis on the legal that makes film and the law in its more legal-centric form so appealing to scholars and students within 
Law Schools (per James Elkins Vermont Law Review 2004 Vol 28, 797 at 824). Work linking into film studies has emerged (Picart, Jacobsen and Greek (2016)) as well as much needed empirical research (Robson and Schulz (2016); Podlas (2009)).

\section{Law and TV}

Whilst scholarship on law and film has flourished, there has been relatively little published on the small-screen lawyer and legal processes. Even in light of the major developments in Spain, where cultural images of law have been examined in extensive detail in a multi-volume series from the Valencia publishers Tirant Lo Blanch under the head of "cine y derecho," (Robson (2009) 117) that work has neglected the broader "cultura popular y derecho" and television representations scarcely feature at all in the 47 volumes produced by June 2017 (www.tirant.com (last consulted 12 June 2017) reveals only The West Wing Law Política Como Promesa (October 2016)). The same holds true for French and Italian scholarship. In Germany, by contrast, there has been extensive debate and scholarship in this area (Machura (2012)).

The dearth of scholarship devoted to television as opposed to cinema in the law and popular culture field is ironic. Television reaches the vast majority of the population. It is more democratic in its processes and distribution mechanism than is film. It provides news, dramas, documentaries and comedies seven days a week, twenty four hours a day. Cinema, the pre-eminent source of mass entertainment since the early 1920 s, is on the decline. Visiting the cinema is now a luxury and is reserved for a relatively small population of Western audiences. The rise of television as the dominant source of entertainment and information, in light of the world's growing focus on the rule of law and international relations, demands consideration in the law and culture scholarship. Robust studies of law and television will complement law school courses on law and literature, law and film, and law and popular culture more broadly. 
Most television scholarship about law focuses on the police and not on legal processes or lawyering (Rafter (2000 and 2006); Lenz (2003)). This is likely because the adjudication phase of law, with lawyers and courts, does not feature in the vast majority of police or prison television dramas. The separateness of the trial process from detention and imprisonment is a consistent feature of a considerable body of programmes in Britain and the United States. The split between the apprehension and the adjudicatory phases is stark with the former dominating television coverage across the world. In a study of 14 countries in 2014 around 95\% of the law and justice programming on television was on the police and the question of crime detection (Robson and Schulz (eds) (2016)).

This is an issue which is being addressed and there is new scholarship developing both analysing the nature of the television product as well as its reception and the production process (Robson and Silbey (eds) (2012)). The allure of the rather more glamorous and seemingly prestigious world of cinema remains, however. One needs to add to this the mundane reality that television series occupy more hours than individual films as well as the older series being unavailable for study. For reasons unconnected with any intrinsic importance as a cultural object there is likely to be a continuation of the existing hierarchy of prestige. Law and literature will continue to enjoy prestige with its links back to the Greeks, Shakespeare and Dickens. The prospects for work between those principally concerned with law and film and the burgeoning field of law and television remain unclear. Existing links need to be strengthened, though, if the full potential for law and popular culture is to be realised by looking at the impact. These possibilities seem more promising, though, than linking the literary and visual worlds. Whether or not this will encompass an examination of the economic structures which determine the content of the culture which we are exposed to is even more problematic but it is a feature which continues to be unfashionable although it is something which the 2016 transnational study addresses (Robson and Schulz (eds) 2016 ). 


\section{Problems in Law and Popular Culture}

It seems to me that there are a number of particular problems within the field of law and popular culture. These centre around the methodology and language adopted within much of the work in the field. There is then the imbalance of resources devoted to television as compared to film. I make a number of suggestions in the spirit of one keen to see this field of interest expand and grow in influence rather than develop into an exotic irrelevant sideline incomprehensible to all but a few specialists.

\subsection{Methodology}

How one decides what the subject matter is and how enquiry should be carried out was an issue largely overlooked in the early scholarship. Here were arresting new resources - the visual media to highlight a range of questions in relation the practice of law. Exactly what one did with this new text was determined by one's traditional method of analysing texts for their "meaning". This was the link between traditional doctrinal "black letter" scholarship and socio-legal approaches. The implications of an interpretation for a single client expanded to look at the class, gender and race impacts. Hence scholars started to use cases and legislation to illustrate the ways in which groups and individuals had exercised authority and power in society. From concrete and specific conflicts over such issues as slavery, inadequate housing or working conditions or the role of power in the family, the waxing and waning of power and influence could be demonstrated. Law, even the common law, was shown then as not simply a set of rigid rules with an impenetrable origin but a battleground of social struggle. Film and TV were no different. They were simply different texts 
which had both clear meaning on the surface as well as other rather more oblique significance and potential meanings. Thus we had The Man Who Shot Liberty Valance seen as a metaphor for two different concepts of the nature of law (Denvir (1996) at 24). One way of law emerging is organically through the will of the people, whilst the other is to be handed "down" from some authoritative source. A slightly different spin was put on the film Thelma and Louise. Spelman and Minow discussed the crucial theme which crops up in both legal discourse as well as more broadly, namely, the role of confidence in the legal system (Denvir loc cit at 270).

Much of this early work was relatively modest in its goals. It often traced how the legal zeitgeist had altered and illustrated this with films (Greenfield, Steve and Osborn, Guy (2005); Strickland, Foster and Banks (2006)). The problem, though is the way in which the cinematic evidence is used as a key to the zeitgeist. How does a trend become significant? How many films should we be looking at? What period of time might we observe? What about the issue of changes in different generations' perceptions of earlier films? I have sought to address these issues in discussing vigilante films. Here the time frame for the relevant films was determined by the impact of censorship banning the cinematic glorification of revenge until the 1970s (Robson (2016 a); Robson (2016 b)).

There are other concerns where we move beyond the imprecise, but hugely attractive boundaries of zeitgeist. Mark Tushnet examines the film Class Action in terms, not of its significance as an illustration of class politics or professional ethics but as a site for psychoanalytic discussion (Tushnet in Denvir op cit at $254 \mathrm{ff})$. He sees the film as a struggle between father and daughter. Austin Sarat, for his part, looks at a range of issues in The Sweet Hereafter. He reads the film for its potential to illustrate psychoanalytic perspectives drawn from Lacan (Sarat (2000). What is interesting in both 
these examples is that they each use the highly contentious perspective of Lacan in relation to the law of the father.

Although the early calls to action on popular culture from Macaulay and Friedman both referred to television, as well as film, most of the work which took up the challenge to examine popular visual culture engaged with film. The role of the first scholars was to provide a stimulating supplement to legal education. The legal education enterprise has traditionally been dominated by professional concerns. What film was used for was to highlight and emphasise. With the new availability of accessible video recordings in the 1990s this work was made considerably easier. An early issue was of the absence of any kind of clear theoretical perspective informing the analysis(Black (1999)). The work looking at different kinds of films had a tendency to be highly descriptive. This stemmed from the nature of the task which scholars were addressing with film. As has been explained in greater detail elsewhere this was a subsidiary role (Osborn (2001). The doctrinal or social science analysis was primary. The film texts were examples of these ideas in action. More recently the films themselves seem to have become the focus. This shift into a cultural or film studies framework alters the nature of the scholarly enterprise. It may produce more rigorous "film" scholarship but does it advance our understanding of such issues as gender, ethnic or class interaction and oppression?

Another stream of activity in law and film centred on the storytelling features of law and film (Silbey (2001)). There is admittedly, a parallel between the way in which trial lawyers seek to construct a narrative and the way in which some cinema is narrative in its form. This common feature of storytelling, though, neither exhausts what is involved in the operation of the justice system nor what occurs in film. Much of day-to-day legal practice is involved in negotiating between parties as to how future relations will be conducted. There will be discussions about how past conduct has not met stipulated criteria. When allied to the complex enterprise of drafting documents to encompass 
these scenarios and prevent against undesired outcomes it is hard to see why this set of practices should be portrayed as storytelling. The narrative convention in film may be dominant but much "art house" and even mainstream cinema takes a very different approach.

The question, though, for us is not so much whether or not the characterisation of law as storytelling is inadequate but, rather whether the range of studies Silbey indentifies as "law-in-film" can be usefully contained within a single framework. I would suggest that different methodologies are at work. Different interests and foci exist. Just as legal scholarship ranges from the doctrinal black letter through socio-legal to philosophical analysis, so too law and film has its distinct constituents. The problem lies in failing to recognise that the distinct approaches come with different sets of criteria of relevance. When scholars shift between different approaches without acknowledging this change, they run the risk of their work being misinterpreted or critiqued for failing to do something which it was not trying to do. Descriptive work or taxonomic surveys often cover extensive amounts of material without appearing to engage explicitly with theory. Theoretical insights, in turn, are sometimes premised on very limited evidence. These limitations need to be addressed in the pursuit of richer scholarship. Whether that is turned, as I would wish to see it, towards demystification of the politics of popular culture, is another issue.

\subsection{Language}

Although this might be seen as the least significant complaint the question does need to raised by scholars. As part of the enterprise of specialisation and perhaps for the less worthy goal of academic kudos, there is a tendency towards increasing written obscurity tending towards obfuscation. Journals expand in both size and numbers and the contents are aimed at specialist 
audiences. The same occurred with Marxist analysis in the 1970s. Those lacking the background in a discipline need not start to read. People who may have thought they were interested in law and literature or critical studies have only to open the Journals catering to these areas to find a bewildering array of language and styles unfamiliar to the standard educated reader. The solution, as always is to purchase a dictionary. Academics cannot be expected to dumb down. They might, however, pause to wonder what their interventions are achieving. Read by few and understood by even fewer, there seems little point in engaging in law and popular culture if the students, members of the profession and the public are excluded effectively from the discourse.

My own goals have always been clear and simple. I see the point of examining law and popular culture as part of a mission to explore how the phenomenon of law affects people in their daily lives, both the positive as well as the adverse impact. I do this in the substantive law classes I teach, working in the tradition developed from realism and now found in critical legal perspectives. Here, in my own case, the classes examine how the protections for those in poverty or who are homeless or subject to discrimination operate using social science data beyond the skeleton of the formal rules and regulations. In countries where inequality abounds and oppression on the basic of class, sexuality, disability, gender and ethnicity are rampant, how is law actually able to challenge those practices? Insofar as the protections offered may be totemic do these imperfect legal solutions buttress the positions of those with lawful authority? Specifically, in relation to popular culture, what is their role in suggesting to us that we are genuinely protected by fine phrases like "reasonable" or "just and equitable" and that worthy concepts like "the rule of Law" are not hollow mockeries like the rights under Stalins' 1936 Constitution? (Getty (1991)). Is the legal world of the movies and television a site for the vindication of ordinary people's struggles in a way which is far removed from the perpetuation of daily injustice? The aim is not to develop new frontiers in film studies but to illuminate and enrich the study of law and justice using popular culture as an 
accessible tool to this end. In broad terms it is instructive to assess whether or not the version of law and justice which is encountered is reflexive and supportive of the status quo or contains within it a critique of the institutions and their working and are refractive (Black (1999) op cit). These are issues which I have considered in the context of the early films of John Grisham's novels (Robson (2001)currently under revisal but with the same broad conclusion) and in the justice films of Sidney Lumet (Robson (2006)) and which strike me as allowing a useful starting point to assess the political significance of popular culture and its changes over time. It is what my colleagues Steve Greenfield and Guy Osborn have sought to do in our collaborative work (Greenfield, Osborn, Robson (2001); Greenfield Osborn and Robson (2007) and Greenfield, Osborn and Robson (2010)).

\subsection{Shifting the Focus}

The tendency in law and popular culture studies in the past, often has been relatively modest in the coverage of films or television material. Scholars have by and large examined individual films and analysed what these had to say to us in relation to issues of law and justice. The majority of the writing in the special collections and Journal pieces have followed this line. Thus, for instance, from Denvir's 1996 Reel Justice and the San Francisco University Picturing Justice symposium through to the Baltimore Law Review Special Collection on Law and Film in 2007 we find writers taking on board individual films like Adam's Rib (Kamir (2000); see also Sanderson and Somerlad (2006)), The Accused (Silbey (2009) and North Country. (Korzec (2007)). The general expectation, as we see in an issue of the International Journal of Law in Context and the treatment of Robocop (Robertson (2008), is to focus on a single film. The problem, of course, is that the conclusions one can draw from a single film are limited. The reading of films changes over time. Alternatively writers have selected a theme and illustrated this with a selection of films. How film has dealt with a particular issue such as capital punishment (Harding (2005)), corporate misconduct (Robertson (2005) or the ethnic minority experience has been explored (Robson (2002). 
Selecting big themes and applying a longitudinal approach is, however, best suited for books and generally less appropriate for the essay format. I am, however, impressed with the approaches of Richard Sherwin and Marianna Valverde. Sherwin adopts an approach which involves looking at both the text and the broad context of the period being examined (Sherwin (1996)). He has sought to draw rather more elaborate conclusions from limited material without, in my view, stretching our credibility. In his examination of the making and re-making of the film Cape Fear, Sherwin draws conclusions about the nature of shifts in American society and the role of lawyers between the late 1950s and the early 1990s. His comments appear perceptive and well-grounded at the general level, although one might cavil that there could be greater social science data on levels of respect for lawyers and changing societal roles of lawyers. Valverde points to the value of locating specific cultural products within their cultural context. She draws our attention to the value of format analysis (Valverde (2006) as a way of differentiating between cultural products to see better how representation is structured and presented. By combining these two approaches I hope to take these cultural phenomena and provide a richer picture than by focusing solely on the different content. I do this looking at products separated in time by 40 years which have the potential to illustrate a changed perception of justice. The objects of my focus are two television series and the goal is to see whether this adds to our understanding of superficially different representations of key actors in the justice system, judges.

I argued some years ago on a number of occasions that television should be looked at in rather greater depth (Robson (2007a); Robson (2007b)) and that to continue with a focus on film cuts down on what we can usefully say in terms of the impact of popular culture on society. The films provide a version of how law operates. The television shows, too, indicate the issues confronting society when systems of justice operate. Here we can see the bigoted jury in To Kill a Mockingbird 
(1962), ignoring the evidence, to convict Tom Robinson and the dangers of vigilante justice in The Star Chamber (1983). We can see the trade-off made by prosecutors to secure a conviction in The Accused (1988). We learn how backstreet abortion blighted the lives of women and their families prior to the legalisation of abortion in Vera Drake (2004). I fully appreciate, and am to a significant degree seduced, by the attractions of the glamour of film but do wonder whether we should not be devoting at least equal time to television. The undernoted is a modest contribution to what I would argue is the only way to develop if we are genuinely interested in the impact of popular culture, as opposed to simply film, in relation to law and justice. Elsewhere I have adopted a similar approach to two television legal series with female protagonists to indicate how the portrayal of feminism and social issues have altered between the early 1970 s and the second decade of the $21^{\text {st }}$ century Robson (2014)).

\section{Assessing the local - from Mr Justice Duncannon to Judge John Deed}

Whilst not wishing to be parochial it also seems to me that it is worthwhile examining TV lawyers in the first place at least in their specific jurisdictional context. It is, I think, vital that the different ways in which such things as how prosecution authorities are constituted, the distinct paths to a judicial career or appointment and how lawyers are paid be recognised in any attempt to survey and assess the representation of the justice system on television. In addition, it is of importance that the structure of the television medium at the specific time and place be noted since this has an impact of the types of programmes made and not made. It may turn out in the end that the links between the versions of TV lawyers encountered in different jurisdictions are overwhelming and that looking at Germany tells us exactly what we gain from looking at the United States or Britain. Similarly the way programmes are produced and financed in different countries may turn out to be much the same. To this end we commissioned essays from a range of 14 different countries on the specifics of 
television programming on law and justice in 2014 (Robson and Schulz (2016)). As we suspected that this was not so. The important thing was to gain a clearer picture from noting the specifics of programmes. Where power lies in making decisions about whether issues are to be pursued in the courts and what kinds of programming receives approval adds to our understanding. At the broader level, this is what we did in the transnational survey in 2014. By way of a further step in this direction the rest of this essay looks in detail at the British legal system as portrayed on television in two series which had a similar focus. One is drawn from 1963 and the other from 2005. Both portray the justice system from the point of view of a High Court judge. It seems to me that this gives us an opportunity to see how law, justice and television itself have altered in the period between the showing of Mr Justice Duncannon and the arrival Judge John Deed.

What is particularly interesting is that in the examination we can see a conscious attempt to create a character and situation which differs from the reflexive status quo supportive scenario that is encountered in much of popular culture's portrayal of justice. In this examination we move from the world and worldview of the British judge and fiction writer of the 1950s and 1960s Henry Cecil to that of contemporary author, Gordon F Newman. We shift from an era of deference to judicial pronouncements to a sustained critique of those interpreting and applying the law. Judges are in the early period ethereal figures almost beyond our ken and absent from the public eye. They do not appear in public discourse. They are amateurs drawn from the practicing Bar and appointed by the senior judge, the Lord Chancellor in an arcane manner meeting unspecified criteria. In the $21^{\text {st }}$ century the role and visibility of judges has not altered. The principal change is that they apply for their posts and their appointment is done through the Judicial Appointments Board. The change in the composition of the Bench from being a collection of white, privately educated middle class men has not been dramatic in the years between 1963 and the turn of the century. 
The legal disputes we encounter in the world of Henry Cecil appear to be cosy. The characters are daft eccentrics. People are well-meaning, if ineffectual. There are scamps and rogues. This is a world of decent folk occasionally overstepping the mark and of genuine misunderstandings. The world of Gordon Newman, as exemplified in his Law and Order series (BBC TV DVD (2006) 1978) and other work is gritty and sleazy. There are really nasty characters. Villains employ shotguns not charm and witty one-liners. Lawyers are happy to provide perjured evidence. Police more than ready to lie and subvert the justice system - to "fit up" any villain who is "due" unless of course enough money can be provided by way of a "bung" (bribe). What one might expect is that the world of Mr Justice Duncannon has been supplanted by a much harder edge picture of judicial work addressing the issues of a politicised legal apparatus in the $21^{\text {st }}$ century Judge John Deed.

\subsection{The Context of TV}

The black and white two channel world of 1963 is the one occupied by Andrew Cruickshank's Mr Justice Duncannon and his fellow judges. One channel is funded by a licence fee payable for all TVs, the other relies on commercial advertising for its income. The BBC where Duncannon appeared made programmes in-house. By the time Judge John Deed appears on the scene he is competing with five terrestrial channels and a multitude of cable and satellite offerings (Robson and Schulz (2016)). He also appears on the public funded channel. External commissioning now takes place within a changed framework of small competitive companies seeking to provide their product to one of many specialised outlets. When Mr Justice Duncannon appeared the level of cinema attendance was still buoyant. By the time Judge John Deed appeared cinema and TV's modes of delivery had altered to accommodate DVDs, home cinema and streaming through the internet. These sit alongside the traditional carefully scheduled TV programming and multiplex cinema releases. Which 
delivery format will determine the market product in the future is far from clear to observers and those within the industry.

One factor which needs to be noted too is the curious paradox of the relative importance of individual television programmes back in the early 1960s and their different status in the new millennium. They are far more plentiful and available from a vast range of sources. The products of the 1960s, though far fewer in number were treated cavalierly. Technological developments mean that it is far easier to produce the programmes as well as to store. We have a situation where something as interesting and path-breaking as Mr Justice Duncannon exists only on the pages of the Frank Muir archive at Sussex University. The tapes are listed in no archive and must be presumed wiped. Thankfully the whole world can obtain access to Martin Shaw's Judge John Deed in the comfort of their own homes, any time with the DVD version.

\subsection{Lawyer portrayals in the $1960 \mathrm{~s}$}

What is, perhaps, initially surprising about the Duncannon portrayal is that it addresses complex issues of justice at a time when either the humorous or sensational side was typically encountered. The lawyer-centred series that were found in 1962 were four in number on British television. On the one hand were two British products and on the other two US imports (Perry Mason (1957-66); The Defenders (1961-65 )). We could watch either Boyd QC solving crimes and appearing in his wig in court. His popularity was reflected in a prime time slot at 8 p.m. on weekday evenings. It ran over 78 episodes for some eight years between 1956 and 1964. He appeared for both defence and prosecution and did not always win his cases. Again the tapes are wiped although 3 episodes are available online. Alternatively for one short period in 1962 there was a comedy offering from the 
BBC, Brothers in Law. This was based on the light hearted writings of county court judge, Henry Leon. He published 24 books between 1951 and 1977 along with three collections of short stories and seven non-fiction works on legal themes. ${ }^{i}$

The success of Brothers in Law both as a book, on the radio and as a 1957 film saw it transfer to television in April 1962. It ran for 13 half hour episodes until 10 July that year. Typical story lines stress Roger Thursby's incompetence in making a plea in mitigation (Brothers in Law Episode 1 broadcast $6^{\text {th }}$ April 1962) and in seeking damages for an industrial injury (Brothers in Law Episode 2 broadcast $13^{\text {th }}$ April 1962). What we are seeing is how a young and inexperienced youth finds his feet at the Bar. He triumphs by accident and whilst it stops short of farce it exploits the situations for laughter rather than to make a pointed critique of the nature of the British justice system or its then amateurish method of legal education. The programmes were shown on a Friday evening at 8.50 p.m. at what has become known as "primetime". The actor taking the part of a judge in the final episode, Counsel for the Prosecution, had just commenced playing Dr Cameron in the adaptation of AJ Cronin's medical stories Country Doctor and The Little Black Bag. These were shown as Dr Finlay's Casebook and ran for 9 years. In his first break from filming this medical series Andrew Cruickshank took the opportunity to reprise his role as Mr Justice Duncannon for a six episode series between January and February 1963.

The style is though rather more serious than that encountered in Brothers in Law. The writers were the same. The basic plots were provided by the same county court judge and writer, Henry Leon, using his non-de-plume Henry Cecil. Comedy tyros, Frank Muir and Dennis Norden were charged with the task once again of collaborating to render the scripts appropriate for transmission. Dialogue 
was not Cecil's strong point. There is an optimism, though, about the outlook. The glass of whisky connoisseur Mr Justice Duncannon is very much half full.

What is interesting is that in this brief excursion into the life and thoughts of a judge, the writers took the opportunity to address serious themes and weighty issues. The style and approach to some extent calls to mind what we find with John Mortimer's Rumpole. The Old Bailey hack seems to be in danger of being remembered as a light comic figure memorable for his spouting of poetry at inappropriate moments, quaffing poor quality claret and being browbeaten by his harridan wife, Hilda (Bergman (2009)) . This image of Horace Rumpole and his self-presentation as a bit of buffoon, however, ignore two things. In the first place, a significant proportion of the storylines in the programmes in which we see Rumpole over the years do feature serious issues. These range from rape (Rumpole and The Honourable Member (1978) and sexual harassment (Rumpole and the Quacks (November $25^{\text {th }} 1991$ ) through police corruption (Rumpole and the Learned Friend (May $1^{\text {st }}$ 1978); Rumpole and the Miscarriage of Justice (November $5^{\text {th }} 1992$ ) and racially motivated crimes (Rumpole and the Fascist Beast (June $19^{\text {th }} 1979$ ) to murder (Rumpole and Golden Thread (October $18^{\text {th }}$ 1983); Rumpole and the Sporting Life (November $8^{\text {th }} 1983$; Rumpole and the Right to Silence (November $11^{\text {th }}$ 1991) and manslaughter (Rumpole and the Summer of Discontent (November $4^{\text {th }}$ 1991). Although Mortimer has a fondness for the "scallywag" Timpson family of south London rogues they actually feature in issues which are themselves of significance, like the manufacturing of evidence and defective identity parades. In addition, it is worth pointing out that this is not just my reading of the Rumpole stories. The intention of the author, John Mortimer, which I am sure he achieved, was to introduce a decent left-leaning liberal politics to his audience. The trick was to do this through the mouth of an apparent pillar of the Established order, the barrister, Horace Rumpole. Mortimer opined about Rumpole's that "he does say a good many of the things I think and if I said them they might sound rather leftish and off-putting, but when given voice by Rumpole they 
become crusty, conservative and much more appealing" (Rumpole of the Bailey (2003) Interview with Sir John Mortimer (DVD, Acorn Media).

In Mr Justice Duncannon the judge also wrestles with issues of some substance. In the first episode, Burden of Proof (MJD (1) transmitted Friday $18^{\text {th }}$ January 1963), for instance he examines what we actually mean by the standard of criminal proof, "beyond a reasonable doubt". His original attempt to turn this standard into common language that one needs to "feel sure" runs into difficulties when the judge tries to explain what this in turn means (MJD (4)transmitted Friday $1^{\text {st }}$ February 1963 shown out of sequence). He is aided and abetted on his quest by fellow judges and by an encounter with a traffic warden. The tone is light but the issue is quite a serious one. The script produces wry smiles rather than belly laughs. In his next outing, Brief to Counsel (MJD (2) transmitted Friday $25^{\text {th }}$ January 1963) the question of judicial bullying and abuse of their position in relation to counsel is explored through the device of having an old flame suggest to Duncannon that he has a reputation as being rude and crusty with young counsel. He duly bends over backwards to be fair only to discover that the young counsel is in fact the son of his lady friend. The same kind of exposure of judicial humanity is seen in The Whole Truth where Mr Justice Duncannon struggles to deal with the issue of truth telling. A religious witness is unwilling to swear an unqualified oath since he points out that only God can know what the truth and that a mere mortal can merely "do his best to tell the truth". The subsequent jailing of the witness and the public outcry on behalf of the wronged wouldbe truth teller foreshadow the whole debate about the relationship between community values and those of the remote figures on the Bench - an issue covered in his fiction like many of Cecil's TV and radio storyline - Friends at Court (1956). In Trial and Error (MJD (5) transmitted Friday $8^{\text {th }}$ February 1963 - shown out of sequence), the issue of judicial bullying of counsel is again raised along with the question of the appropriateness of imprisonment as opposed to imposing a fine on someone who is well-off and would not notice the impact of a fine. We then see how judges have different 
personalities and distinct ways of seeing the law and interpreting evidence in A Case of Whisky (MJD (3) transmitted Friday $15^{\text {th }}$ February 1963 - shown out of sequence). Again the approach is quite cerebral but like the previous encounters we see our protagonist's judicial omniscience being exposed at the end of the episode. Finally, in the last numbered script, Orders Not to Pay (MJD (6) transmitted Friday $22^{\text {nd }}$ February 1963 - shown out of sequence ) we encounter Mr Justice Duncannon being hoist by his own petard again when required to admit that the rule which he had stated as the law in his edition of a textbook on recovery of debts was "ill-considered and superficial".

Here, then we have a picture of a judge who is human. Whilst being by no means a modernist he does not have self-conceit. What the series showed, though, was the extent to which the judge is at the mercy of others in terms of setting an agenda. It also indicated the dramatic possibilities as well as limitations of the judicial format for ensuring discussion of interesting and conflicting ideas. Some in the Duncannon series were thrashed out in court with the sparring of counsel and the judiciary (Brief to Counsel (25 January 1963); Orders Not to Pay (22 ${ }^{\text {nd }}$ February 1963). Others involve judges in discussion in court (A Case of Whisky $\left(15^{\text {th }}\right.$ February, 1963) or providing informal soundings and advice to Mr Justice Duncannon (The Whole Truth (1 $1^{\text {st }}$ February, 1963). Contacts with members of the public were also used to provide a forum for debate (Trial and Error ( $8^{\text {th }}$ February 1963) discussion with wife of counsel over abuse of power by powerful people ; Burden of Proof (loc cit) discussion with traffic warden over witness credibility). Mr Justice Duncannon played a man who had not married and no family was ever alluded to so that the possibility of chewing over the issues confronting him in his work had no domestic forum. It seems clear, though, from the flow of legal stories and simplicity of the settings mean that further series could have been managed. In the Cecil books we read of the development in the character of Roger Thursby from raw and inexperienced barrister in 1955 (Brothers in Law (1955)( Michael Joseph,London), to Queen's Counsel in 1956 
(Friends in Court (1956)( Michael Joseph,London)), and finally on to the bench in 1958.( Sober as a Judge (1958)( Michael Joseph,London). The first stage provided us with 13 TV episodes and some 39 radio programmes. Andrew Cruickshank, the embodiment of Mr Justice Duncannon, however, returned to take up his medical duties as Dr Cameron in the long-running and hugely successful TV series Dr Finlay's Casebook (1962 - $1971-8$ series and 178 episodes ) ministering to douce rural Tannochbrae and, perhaps, more importantly, the industrial urban Knoxhill. Cecil also had an interest in reflecting on the legal system and in its operation in his non-fiction works (Brief to Counsel (1958 and 1972)(Michael Joseph); Not Such an Ass (1961)(Hutchinson, London); The English Judge (1970)(Stevens, London) and to an extent in his autobiography Just Within the Law (1975)(Hutchinson,London) - chapters 14 - 17. Like his fiction, he has greater affection for the system of justice than animus against it defects. Cecil continued to produce a stream of stories up until his death in 1977. Given slightly different circumstances, particularly the unavailability of the principal actor, then, the brief experiment with Mr Justice Duncannon could have had a longer life and the concept of the judicially centred TV drama might have become less of a rarity.

\subsection{Developments in the $20^{\text {th }}$ century}

Why it took another 40 years before a judge took centre stage needs to be placed in some kind of context. The early programmes mentioned above have been followed by a huge number of different kinds of portrayals of both the justice system and law in general. Both police procedurals and court centred programming has been an ever present on our screens. Much of this has been home produced providing versions of the British systems. Here is a template in which high drama can be played out with a clear resolution and miriad different plot lines. At its most basic the thrice weekly series Crown Court lasted for some 12 years and 735 episodes. The ever-present themes of the loss of liberty, damage to feelings and reputation and tales of cruelty and heartbreak that pass through 
the courts on a daily basis mean that there is an apparently endless fund of fresh narratives. The trick has been over the past 50 years how to package these in different ways for new audiences. Although the 1970s saw a female protagonist in Justice (1972 - 4-26 episodes) and an ethnic minority lead in Black Silk (1985 - 8 episodes) only a handful of British offerings have been as longrunning as the series Sutherland's Law (1973-76-46 episodes), where the inquisitorial role of the Scottish Procurator Fiscal was embellished to provide us with a detective series dressed up as a lawyer show. The success of L.A. Law in returning us to the lawyer's office in the 1980s has led most subsequent efforts at legal drama series to replicate the ensemble style. Even the series which focused on an individual like Rumpole and Kavanagh QC have used the "case/home/office" structural divisional device to allow for a range of different relationships and perspectives to be covered. In these series we have the three distinct compartments of the legal case and its progress in court. This is set in the context of developments and tensions within the workplace environment. To these features are added the vicissitudes of family life in a variety of ways.

\subsection{The New Millennium}

The era since 2000 has been particularly fruitful not simply in the number of British TV lawyers on show but their diversity. There is a sense in which writers and producers have confidence in the "legal drama" format. We have seen a parade of different groups of lawyers seeking to capture the public imagination - and viewing figures. These have principally been based around a recognised TV face - Close and True (2000) with multi-series TV star Robson Green and long-established television actor James Bolam; In Defence (2000) with soap star Phil Mitchell (Ross Kemp); Fish (2000) with Dr Who star Paul McGann; Trust (2002) again with Robson Green; The Brief (2004) with comedy star Alan Davies; Outlaws (2005) with Quadrophenia actor Phil Daniels; New Street Law (2007-2009) with screen star John Hannah and comedian John Thompson; Kingdom (2008-2009) with popular TV 
polymath Stephen Fry and Silk (2011-2014) with one of Britain's leading TV and stage actors, Maxine Peake. They also included ensemble pieces of relative unknowns - Wing and a Prayer (1997), Mortimer's Law (1998) North Square (2000) (Robson (2007b) op cit at 82 - 84) and Coroner (2015). They were all conventional in their focus on a legal practice and the work of its members pursuing justice in a range of different court settings. None was successful in securing a long run and becoming the new Rumpole or Kavanagh Q.C.. The reasons ranged from poor reviews to lack of the availability of actors with fresh projects to low audience figures.

The "office" or "barristers' chambers" mould, though has been well and truly broken with the setting of such entertainment in a judge's chambers in Judge John Deed. The series was created, written and produced by Gordon F Newman. Known for his coruscating exposé of the corruption of the world of justice in his 1978 series, Law and Order, Newman sees the glass as already smashed and ready to use on someone. Eschewing the conventional, Newman chose to use the unlikely setting of the High Court some 40 years since Mr Justice Duncannon had been the focus for a legal series. Whilst there is a sense with Mr Justice Duncannon that he is merely reacting to what life throws up in his court, Judge John Deed has an agenda. Despite the patent fact that the judiciary have no role in the allocation of what issues are brought before the courts, we get the feeling that Deed is in control. He is fishing in the streams of litigation for cases that will give him the opportunity to ensure that injustice is rooted out. From his unprivileged working class Northern background he knows that all is not as it seems in the world of law.

Unseen and powerful forces are seeking to influence the smooth running of his courts. These may take the form of the Government with an interest in ensuring that some individual receives special treatment (Rough Justice $\left(26^{\text {th }}\right.$ November 2001) - MI5 informer whose sentence for domestic abuse 
is to be nominal) or of the private construction industry seeking to minimise their responsibility for breaches of health and safety regulations which have led to the death of a young casual worker on one their sites (Duty of Care ( $3^{\text {rd }}$ December 2001) - corporate manslaughter charges reinstated at the behest of Deed). The military and diplomatic world are also secretive and loath to open up to the scrutiny of the justice system (Silent Killer (27 January 2006); War Crimes ( $9^{\text {th }}$ January 2007); Evidence of Harm (26 ${ }^{\text {th }}$ January 2007). The set-up of the Judge John Deed series, is however, utterly unlike that of his 1960s predecessor. Not only does Deed have a family but he has a split and dysfunctional family. He is related by marriage to a senior member of the judiciary as well as having both his daughter and his sometime mistress working as barristers and often appearing before him. He also comes into frequent contact with his ex-wife whose father is an influential senior judge. The opportunities for ethical conflicts are extensive although these are glossed over as the "Establishment" seek to discipline and control Deed. The mysterious Lord Chancellor's Department attempts to restrict and limit what Deed can do. Deed uses his own informal network of contacts to protect and further his own interests - which are, of course, noble. Deed is not venal. He is promiscuous and sexually irresponsible but he retains within him the heroic commitment to his vision of justice. In one early instance, a man, who is so overwhelmed by grief at his daughter's death that he seeks revenge on the perpetrator, will not defend himself. Deed manages to manoeuvre the unwilling defendant to make a pre-sentence statement that allows the jury to change its mind and find him not guilty (Exacting Justice ( $9^{\text {th }}$ January 2001). The rationale for Deed's action is a simple gut instinct that this man does not deserve a life sentence for reacting just as Deed would have done had his own daughter been run over by a dangerously driven car.

Within his world Deed has powerful allies in the lower court officials. His P.A., Rita "Coop" Cooper, is happy to accept the pejorative term used for these vital cogs in the machinery of justice, by one of the judges. To him they are POLEs - persons of low esteem. They are able to protect Deed from the 
oversight that the Lord Chancellor's Department (LCD) would wish to exercise over Deed's professional and personal life. This conflict is given a personal edge through the device of having Deed conduct a brazen affair with the wife of one of the senior civil servants in the LCD. Deed, then is the classic rogue figure with whom TV viewers are familiar from popular culture. He is brilliant but not one to be cowed by the rules. From cinema we are familiar with Harry Callahan (Dirty Harry (1971); Magnum Force (1973); The Enforcer (1976); The Dead Pool (1988) and Martin Riggs (Lethal Weapon (1987); Lethal Weapon 2 (1989); Lethal Weapon 3 (1992)I Lethal Weapon 4 (1998). In television we know our detectives will be dismissive of doing the paperwork and will be happy to cut corners in pursuit of instinctive policing. The line is long in Britain from Endeavour Morse (Inspector Morse; Endeavour ) and Andy Dalziel (Dalziel and Pascoe) to Jack Frost (Frost) and Jim Taggart (Taggart). The trope is so well recognised that it is hard to think of a "justice" series where the hero is not at odds with the authorities and their restrictions. What Newman has done is to transfer this characteristic to a place where following strict procedures would seem to be a quintessential feature of the role. He has shown us that law can be flexible in the right hands and that even apparently rigid, hierarchical institutions like the law are capable of a degree of flexibility. This is done in a series where contemporary controversies are also raised including race (Hard Grating (6 $6^{\text {th }}$ January 2006)) and a wide range of medico/legal issues (Hidden Agenda (1 $7^{\text {th }}$ December 2001); Nobody's Fool $\left(12^{\text {th }}\right.$ December 2002); Everyone's Child (19 ${ }^{\text {th }}$ December 2002); Health Hazard (27 $7^{\text {th }}$ November 2003); Separation of Power (10 $10^{\text {th }}$ February 2005); Lost Youth ( $2^{\text {nd }}$ January 2006); Silent Killer $\left(27^{\text {th }}\right.$ January 2006); Heart of Darkness (10 $10^{\text {th }}$ February 2006), as well as the dangers of reality TV (Popular Appeal $\left(17^{\text {th }}\right.$ February, 2005)).

\section{Assessing the television judges and their eras}


It is the contrast between the two judicial portrayals that appears at first glance to provide a clear snapshot of two very different eras. Examining the individual lawyer programmes between 1962 and 2005 we can see a shift with some themes and issues remaining constant and others changing quite markedly. Sexism and racism are an ever-present. The abuse of power by police and lawyers recurs. Looking though at the world of Mr Justice Duncannon, on the one hand, and his successor, Judge John Deed, on the other, the difference might seem to have been truly seismic. The change, though, is in superficial style more than in substance. It is possible to read Cecil as fluffy and insubstantial and Newman as gritty and realistic (Robson (2014)). One is just light entertainment and the other providing a powerful social critique. Mr Justice Duncannon might seem to be the great uncle of Stephen Fry's $21^{\text {st }}$ century creation, market town solicitor Peter Kingdom (Kingdom - $1^{\text {st }}$ series $2007 ; 2^{\text {nd }}$ series $-2008 ; 3^{\text {rd }}$ series - June 2009 . Critically panned but with strong audience figures of 6 million + leading to re-commissioning). This world of comfortable minor problems with eccentric British characters in which problems vanish when common sense prevails is classically supportive of the established order. In fact, the similarities are rather more extensive and the tradition of thoughtful reflection which Mr Justice Duncannon brings to social and legal questions is encountered in the subsequent work. What has really altered is the context of much more fully realised personal life. Beneath the quizzical gaze of Mr Justice Duncannon quite profound questions are raised to which there are no simple pat solutions. Cecil's achievement was to dress these debates in the flummery of the British courtroom scene. Perhaps, like his successor as the leading British author on legal topics John Mortimer, he was able, thereby, to achieve a more palatable style of debate.

The problem, though, of course for both Cecil and Mortimer is that what people tend to remember is the style not the substance. What remains, like Lewis Carroll's cat is the grin. Paradoxically a related problem occurs with our reading of Judge John Deed. What we remember are his lurid sexual 
encounters. The profoundly serious issues in the cases pale by comparison with his unjudicial private life and his personalised jousting with the Establishment .

The question of context also needs to be factored into any assessment of these two distinct cultural products. It is not so much that the nature of society and social issues have not actually changed so much as how the two writers provide their vision of their society. At the time when Henry Cecil was writing his unthreatening accounts of the travails of untrained amateur ingénu, Roger Thursby and his like, the police were fabricating evidence; judges like Lord Goddard were giving highly prejudicial charges to juries in capital murder cases - provided word for word from the court transcript in Let Him Have It (1989); razor gangs in Glasgow were causing mayhem; Teddy Boys were swaggering through the streets - although the Teddy Boy phenomenon can be seen as a "moral panic" produced by the press headlines there was involvement of some of their number in the race riots of 1958 and racial tensions and attacks in Nottingham and Notting Hill were taking place. The contemporary British films of the time painted different portraits of Henry Cecil's Britain. A steady stream of postWar British films showed a society riven by lack of opportunity, poverty, alienation and conflict. The conflicts are sometimes profoundly political as in the IRA drama Odd Man Out (1946). The focus may be on lives which are drab and only tangentially connected with law - It Always Rains on Sunday (1947) or there may be a central focus on organised crime and gangsters - Brighton Rock (1947) or youth and gang culture -The Blue Lamp (1949). Here, however, is a Britain unrecognisable from watching sanitised versions of the justice system like Eight O'Clock Walk (1953), Witness for the Prosecution (1957) or Brothers in Law (1957). The point is not really which of these versions is more accurate but that they represent two facets. One is a focus on a particular segment of society. The other is the level of optimism of the writing. 
Social realism and escapist drama are two very different kinds of film but the contrast between early sixties films like The Boys (1961) and The Fast Lady (1963) is instructive. Both involve at some point the courts and we see two very different Britains. The Boys, taking its cue from Ted Willis' essays on British social relations, No Trees in the Street (1958) and Flame in the Streets (1961) paints a bleak picture of a narrow and introspective British society. The Willis films ask questions about social inequality and prejudice in the same way as showing a restless dangerous almost film noir version of Britain. Allied to the rejection of an unyielding class system seen in Room at the Top (1958) and Saturday Night and Sunday Morning (1960) we have a perspective which stresses the urban backdrop to crime and order problems (Hutchings (2001). The Fast Lady, on the other hand, is in the tradition of Doctor in the House (1953), Genevieve (1953) and The Constant Husband (1955) and finds us in a country of mild eccentricity where people rub along tolerably well. To highlight this point, we can look at two of Sir Cliff Richard's films to see the contrast. In one we have the depressing alienated youth culture portrayed in Serious Charge (1959) and in the other its upbeat equivalent in The Young Ones (1961) - see also What a Crazy World (1961) for a cheerful rendering of poverty - and racial strerotypes played out for comic effect. Same settings and characters but with a positive mood change. Writers and commentators like Gerald Gardiner (Gardiner and Martin (1963)), Ludovic Kennedy (Kennedy (1964)), and David Yallop (Yallop (1967), in contrast to Cecil's non-fiction, adopted a distinctly more pessimistic approach stressing that the legal system, in particular, might have fine visually uplifting traditions but that these were leading to serious miscarriages of justice. In the world of Mr Justice Duncannon we have a baffled kind of optimism that we will muddle through. Judge John Deed knows that the forces of self-interest will not be easily thwarted and that the prospects for social stability hang by a thread. The world where there is filmic reflection on British social life hardly figures in the time of John Deed. It has been replaced by fantasy cinema. This ranges from the hobbits of Tolkien in the Lord of the Rings trilogy, the spoof spy Johnny English and the James Bond franchise. It is left to niche "arthouse" directors Ken Loach (My Name is Joe (1998); Bread and Roses (2000); Sweet Sixteen (2002); Ae Fond Kiss (2004)). and Mike 
Leigh (Secrets and Lies (1995); All or Nothing (2002); Vera Drake (2004)) to shine a light on contemporary poverty, racism and alienation. The televisual world of reality TV, soap operas and medical series are where we go for ethical conflicts. The judge wrestles with his dilemmas on his own. His world is not different from that of his predecessor. Dangers and moral panics abounded in the early 1960s with multiple murderers Peter Manuel, Myra Hyndley and Harry Roberts in our lives. They have, however, been glossed over and largely forgotten in a rosier recollection of the world inspired by catchy pop songs, Mini Coopers and England winning the World Cup - all packaged together along with witty gangsters in The Italian Job (1969).

\section{Concluding Remarks}

When in the mid 1980s calls went out for scholars to look beyond the actual operation of the legal system to see how this world was presented in the media this opened a new and exciting chapter in socio-legal scholarship. Those very first examples mixed comments about film and television in equal measure. Much ink has since been spilt in this area. The dangers I alluded to at the beginning of this essay are beginning to be confronted. It seems to me that a great opportunity is being lost to investigate how representations affect those who learn from them if the future does not assess the whole field, including television. Simply offering readings of films at one moment in time does not adequately address these concerns. Moreover, this work with an altered focus also would do well to go beyond the contested meanings of these works and look at the impact on opinion, ideally at different times and on different groups. Obtaining the resources to conduct extensive empirical research is another question. The majority, however, of the more recent work still focuses on the big screen. It would be a sad day if the attractions of a tangential connection with the glamorous world of film and of providing a reading of individual films were to continue to skew the efforts and 
scholarship of writers to the detriment of a rich plural picture of how law and popular culture interact. 


\section{BIBLIOGRAPHY}

Abel-Smith, Brian and Stevens, Robert (1967) Lawyers and the Courts (London, Heinneman)

A Symposium on Film and the Law Oklahoma City University Law Review 1997 Vol 221

Aristodemou, Mària (2000) Law and Literature (Oxford University Press, Oxford)

Asimow, Michael (ed) (2009) Lawyers in Your Living Room: Law on Television (ABA, Washington)

Asimow, Michael, Brown, Kathryn and Papke, David (eds)(2014) Law and Popular Culture :

International Perspectives (Cambridge, Cambridge Scholars Press)

Asimow M; Greenfield, S; Guillermo J; Machura S; Osborn G; Robson P; Sharp C and Sockloskie R (2005) Perceptions of lawyers: a transnational study of student views on the image of law and lawyers 12 International Journal of the Legal Profession 407

Asimow, Michael and Mader, Shannon (2004) Law and Popular Culture (Lang, New York)

Bergman, Paul (2009) Rumpole and the Bowl of Comfort Food [ in Asimow ed Lawyers in Your Living Room: Law on Television (ABA, Washington)

Bergman, Paul and Asimow, Michael (1996) Reel Justice - The Courtroom Goes to the Movies (Andrews and McMeel, Kansas)

Bergman, Paul and Asimow, Michael (2006) Reel Justice - The Courtroom Goes to the Movies (2 ${ }^{\text {nd }}$ ed)(Andrews and McMeel, Kansas)

Black, David (1999) Law in Film: Resonance and Representation (University of Illinois Press, Urbana and Chicago) 
Chase, Anthony (2002) Movies on Trial: The Legal System on the Silver Screen (The New Press, New York)

Denvir, John (ed) (1996) Legal Reelism: Movies as Legal Texts (University of Illinois Press,Urbana and Chicago)

Denvir, John (2004) The Slotting Function: How Movies Influence Political Decisions 28 Vermont Law Review, 799

Elkins, James (2004) Reading/Teaching Lawyer Films 28 Vermont Law Review, 797

Faller, Lincoln (1993) Crime and Defoe: a new kind of writing (Cambridge University Press, Cambridge)

Freeman, Michael and Lewis, Andrew (eds) (1995) Law and Literature (Oxford University Press, Oxford)

Freeman, Michael ed (2005) Law and Popular Culture (Oxford, University Press, Oxford

Gardiner, Gerald and Martin, Andrew (eds) (1963) Legal Reform Now (Gollancz, London)

Gest, John (1913) The Lawyer in Literature (Sweet \& Maxwell, London) (reprinted 1999 
Getty J Arch (1991) State and Society under Stalin: Constitutions and Elections in the 1930s Slavic Review Vol 50 No 1 (Spring) 19

Goodrich, Peter (1996) Law in the Courts of Love: Literature and Other Minor Jurisprudences (London, Routledge)

Greenfield, Steve and Osborn, Guy (2005) The Double Meaning of Law: Does it Matter if Film Lawyers are Unethical [ in Law and Popular Culture Freeman M (ed) ] 638

Greenfield Steve and Osborn Guy (2006) (eds) Readings in Law and Popular Culture (Routledge, Abingdon)

Greenfield, Steve, Osborn, Guy and Robson, Peter (2007) Genre, Iconography and British Legal Film Vol 36 Baltimore Law Review Law and Cinema Special Issue 371

Greenfield, Steve, Osborn, Guy and Robson, Peter (2001) Film and the Law (Cavendish, London)

Greenfield, Steve, Osborn, Guy and Robson, Peter (2010) Film and the Law: the cinema of justice (Hart, Oxford)

Greycar, Regina Telling Tales: Legal Stories about Violence against Women Vol. 8, No. 2, Boalt Hall: Law and Literature Symposium. Part 1 (Autumn - Winter, 1996), pp. 297-315

Guéry, Christian (2007) Justices à l'écran (Institut des Hautes Etudes sur la Justice, Paris); 
Gunn, David (ed) (1993) The Lawyer and Popular Culture: Proceedings of a Conference (Fred B Rothman, Littleton)

Harding, Roberta (2005) Reel Violence: Popular Culture and Concerns about Capital Punishment in Contemporary American Society [ in Law and Popular Culture Freeman M (ed) ] 358

Harris, Thomas (1987) Courtroom's Finest Hour in American Cinema (The Scarecrow Press, Inc. Metuchen, NJ \& London)

Harris. Brian (ed) (1998) The Literature of the Law (Blackstone Press, London)

Hutchings, Peter (2001) Beyond the New Wave: Realism in British Cinema 1959-63 [ in Murphy ed The British Cinema Book (BFI, London)

Jarvis, Robert and Joseph, Paul (1998) Prime time law : fictional television as legal narrative (Durham, N.C. : Carolina Academic Press)

Kamir, Orit (2000) "X - Raying Adam's Rib: Multiple Readings of a (Feminist?) Law-Film" Studies in Law, Politics and Society Vol 22 103;

Kamir, Orit (2006) Framed: Women in Law and Film (Duke University Press, Durham, North Carolina)

Kennedy, Ludovic (1964) Ten Rillington Place (Gollancz, London)

Kornstein, Daniel (1994) Kill All the Lawyers? Shakespeare's Legal Appeal (Princeton University Press) 
Korzec, Rebecca (2007) Viewing North Country: sexual harassment goes to the movies Vol 36 Baltimore Law Review Law and Cinema Special Issue 303

Law and Cinema Special Edition Baltimore Law Review 2007 Vol 36;

Law and Film Journal of Law and Society 2001 Vol 29

Law and Popular Culture 1998 Legal Studies Forum Vol 22, 3

Law in Film/Film in Law Vermont Law Review 2004 Vol 28, 797

Lenz, Timothy (2003) Changing Images of law in film and television crime stories (Peter Lang, New York)

Levi, Ross (2005) The Celluloid Courtroom: A History of Legal Cinema (Praeger, Westport CT)

Linera, Miguel Angel Presno, and Rivaya, Benjamin (eds) (2006) Una introducción cinematográfica al derecho [ A Cinematic Introduction to Law]

Lucia, Cynthia (2005) Framing female lawyers : women on trial in film (University of Texas Press, Austin) 
Macaulay, Stewart (1987) Images of Law in Everyday Life: The Lessons of School, Entertainment and Spectator Sports 21 Law and Society Rev 185

Machura, Stefan (2011) Media Influence on the Perception of the Legal System (in Papendorf, K, Machura S and Andenæs K (eds) Understanding Law in Society (Zurich and Bwerlin, Lit Verlag )

Machura, Stefan (2012) The German Sociology of Law: A case of Path Dependency International Journal of Law in Context 8, 506-523

Machura, Stefan, Love, Thomas and Dwight, Adam (2014) Law Students' Trust in the Courts and the Police 42 International Journal of Law, Crime and Justice 287 - 305

Machura, Stefan (2016) Law and Cinema Movement (in Picart, Jacobsen and Greek 2016)

Machura, Stefan and Robson, Peter (eds) (2001) Law and Film (Blackwell, Oxford)

Masson, Antoine and O'Connor, Kevin (2007) (eds) Representations of Justice (Peter Lang, Bruxelles)

Meyer, Phil (2001) Why a Jury Trial is More Like a Movie than a Novel 28 (1) Journal of Law and Society 133

Moran, Leslie, Sandon, Emma, Loizidou, Elena and Christie, lan (eds) (2004) Law's Moving Image (Glasshouse Press, London) 
Morison, John and Bell, Christine (eds) (1996) Tall Stories? Reading Law and Literature (Dartmouth, Aldershot)

Nieto, Francisco Soto and Fernández, Francisco J (2004) Imágenes y Justicia: el derecho a través del cine [Images and Justice; law through cinema] (La Ley, Madrid)

Ogletree, Charles and Sarat Austin (2015) Punishment in Popular Culture (New York University Press, New York

Osborn, Guy (2001) Borders and Boundaries: Locating the Law in Film [ in Law and Film eds Machura and Robson ]

Picart, Caroline, Jacobsen, Michael and Greek, Cecil (eds) (2016) Framing Law and Crime: an interdisciplinary anthology (Farleigh Dickinson University Press, Madison, Teaneck)

Podlas, Kimberlianne (2009) Impact of Television on Cross-Examination and Juror 'Truth' 14 Widener Law Review 483

Podlas, Kimberlianne (2012) Testing Television: Studying and Understanding the Impact of Television's Depictions of Law and Justice (in Robson, P and Silbey, J (eds) Law and Justice on the Small Screen (Oxford, Hart)

Posner, Richard (1988) Law and Literature (Harvard University Press, Cambridge, Mass) 
Puaux, Francoise (ed) (2002) La justice à l'écran 105 CinémaAction (Corlet- Telerama, Conde-surNoireau)

Race, Law and Film 1998 Asian Law Journal, 1

Rafter, Nicole (2000) Shots in the Mirror (Oxford University Press, Oxford)

Rafter, Nicole $\left(2006,2^{\text {nd }}\right.$ ed) Shots in the Mirror (Oxford University Press, Oxford)

Rapping, Elayne (2003) Law and Justice As Seen on TV (New York University Press, New York)

Robertson, Michael (2005) Seeing Blind Spots:Corporate Misconduct in Film and Law [ in Law and Popular Culture Freeman M (ed) ] 385

Robertson, Michael (2008)Property and privatisation in RoboCop International Journal of Law in Context, 4.3, 117

Robson, Peter (1979) Housing and the Judiciary (Glasgow, University of Strathclyde)

Robson, Peter (1996) Images of Law in the Fiction of John Grisham (in Tall Stories? Reading Law and Literature (Morison, J and Bell, C (eds)) (Dartmouth, Aldershot)

Robson, Peter (2001) Adapting the modern law novel: filming John Grisham (in Law and Film (eds) Machura and Robson) 
Robson, Peter (2002) Fade to Grey: portraying the ethnic minority experience in British film International Journal of the Sociology of Law 3, 235

Robson (2005) Law and Film Studies; Autonomy and Theory (in Freeman 2005)

Robson, Peter (2006) The Justice Films of Sidney Lumet ( in Readings in Law and Popular Culture Greenfield and Osborn eds (Routledge, London and New York)

Robson, Peter (2007a) Lawyers and the legal system on TV: the British experience International Journal of Law in Context, 2.4, 333 - 362;

Robson, Peter (2007b) Developments in Law and Popular Culture: The Case of the TV Lawyer [ in Representations of Justice eds Masson and O'Connor ] (Peter Lang, Bruxelles) 75 - 93

Robson, Peter Law, Hollywood and the European Experience, (2009) Studies in Law, Politics and Society: Symposium on Film, 117.

Robson, Peter (2014) The Law Through the Eye of Courtroom Comedy: The Light Legal Procedural in Context (in Law and Popular : International Perspectives Asimow, Brown and Papke (eds) (Cambridge, Cambridge Scholars Press)

Robson, Peter (2014) Women Lawyers on TV - the British Experience Nordic Journal of Law and Social Research No 5, 101 - 116

Robson, Peter (2016 a) Beyond the Courtroom: Vigilantism, Revenge and Rape-Revenge Films in the Cinema of Justice (in Picart, Jacobsen and Greek (eds)) Farleigh Dickinson UP, Madison, Teaneck )

Robson, Peter (2016 b) Vengeance in Popular Culture Oxford Research Encyclopedia Criminology and Criminal Justice December (at www.criminology.oxfordre.com last consulted 12 June 2017)

Robson, Peter and Schulz, Jennifer (eds) (2016) A Transnational Study of Law and Justice on TV (Hart, Oxford) 
Robson, Peter and Silbey, Jessica (eds) (2012) Law and Justice on the Small Screen (Hart, Oxford)

Salzmann V and Dunwoody P (2005) Do Portrayals of Lawyers Influence How People Think About the Legal Profession 58 Southern Methodist University Law Review 411

Sanderson, Peter and Somerlad, Hilary (2006) Gender, power and law in screwball comedy: reviewing Talk of the Town and Adam's Rib [ in Greenfield and Osborn (eds) looking at both Adam's Rib and Talk of the Town

Sarat, Austin (2000) Imagining the Law of the Father: Loss, Dread and Mourning in the Sweet Hereafter 34 Law and Society Rev, 5

Sarat, Austin, Douglas, Lawrence and Umphrey, Martha eds (2005) Law on the Screen (Stanford University Press, Stanford)

Sharp, Cassandra and Leiboff, Marett (eds) (2016) Cultural Legal Studies: Law's popular cultures and the metamorphosis of law (Routledge, Abingdon and New York)

Sherwin, Richard (1996) 'Cape Fear: Law's Inversion and Cathartic Justice' 30 University of San Francisco Law Review, 1023

Sherwin, Richard (2000) When Law Goes Pop: The Vanishing Line Between Law and Popular Culture, (University of Chicago Press, Chicago);

Silbey, Jessica (2001) Patterns of Courtroom Justice (in Machura and Robson (eds) )

Silbey, Jessica (2007) Truth Tales and Trial Films, 40 LOY. L.A. L. REV. 551 at 557 fn 29 
Silbey, Jessica (2009) A Witness to Justice (in Studies in Law Politics and Society ed Sarat) 61 - 91

Stark, Steven (1987) Perry Mason meets Sonny Crockett: the history of lawyers and the police as television heroes 42 University of Miami Law Review 229

Strickland, Rennard, Foster, Teree and Banks, Taunya (eds) (2006) Legal Reelism: The Hollywood Film as Legal Text

Symposium on Law and Film 1991 Legal Studies Forum Vol 15, 199

Symposium: Picturing Justice: Images of Law and Lawyers in the Visual Media 199630 University of San Francisco Law Review, 891

Thornton, Margaret (ed) (2002) Romancing the Tomes (Cavendish, London)

Tomeo, Vincenzo (1973) II Giudice Sullo Schermo (Bari, Laterza)

Valverde, Mariana (2006) Law and Order: Images, Meanings and Myths (Routledge-Cavendish, London) at $42 \mathrm{ff}$

Villez, Barbara (2005) Séries Télé: visions de la justice (Presses Universitaires de France, Paris)(available in English (2010) Television and the Legal System (Routledge, London))

Wagner, Anne and Sherwin, Richard (2014) Law, Culture and Visual Studies (Dordrecht, Heidelberg, New York, London)

Ward, Ian (1995) Law and Literature (Cambridge University Press, Cambridge) 
Ward, Ian (1999) Shakespeare and the Legal Imagination (Butterworths, London)

Yallop, David (1967) To Encourage the Others (Gollancz, London)

\begin{abstract}
' Novels - The Painswick Line (1951); No Bail for the Judge (1952); Ways and Means (1952) ; Natural Causes (1953) ; According to the Evidence (1954) ; Brothers in Law (1955) ; Friends at Court (1956); Much in Evidence (1957) ; Sober as a Judge (1958) ; Settled Out of Court (1959); Alibi for a Judge (1960) ; Daughters in Law (1961) ; Unlawful Occasions (1962) ; Independent Witness (1963); Fathers in Law (1965); The Asking Price (1966) ; A Woman Named Anne (1967) ; No Fear or Favour (1968) ; Tell You What I'll Do (1969) ; The Buttercup Spell (1971) ; The Wanted Man (1972) ; Truth With Her Boots On (1974); Cross Purposes (1976); Hunt the Slipper (1977). Short story collections - Full Circle (1948); Portrait of a Judge (1964) ; Brief Tales from the Bench (1968) - all published by Michael Joseph, London.
\end{abstract}

